Zazili Mustopa, Doctorate Program of Economics Science Student, Sriwijaya University, Palembang, Indonesia e-mail: zazili.1971@gmail.com

Azwardi, Lecturer at the Faculty of Economics, Sriwijaya University, Palembang, Indonesia e-mail: azwardi_unsri@yahoo.com

\title{
Factors Decreasing Water Crossing Retribution as One of Regional Own Source Revenue of South Sumatera Province in 2017
}

\begin{abstract}
Introduction. The results of documentation study on Regional own source Revenue of South Sumatra Province indicated a problem, especially in crossing water retribution, there was a decreasing on crossing water retribution income from over the years of Rp. 2013 to 2014 total of Rp. 374,169,677,639, , and dramatically happened again into Rp. 2,170,078,883 in 2015, so that crossing water retribution became Rp. 47,350,000.

Purpose. The purpose of this study was to find out the factors decreasing water crossing revenues in South Sumatra Province. The research used qualitative method. The technique of collecting data used interviews, observation, and documentation. To analyze the data the researcher used qualitative analysis.

Results. The results of the study showed that the cause of water crossing retribution of South Sumatra Province in 2017 decreased due to uncooperative retribution payers paying bill payments, both individuals and companies. The uncooperative attitudeswere shown in late payment bills, even after bills were given. More concerning factor was the existence of retribution payers who did not pay retribution according to the bill issued. The reason given by them was inappropriate between services and fees that must be paid. In addition, there were also companies objected to pay bec ause the large amount of retribution charged.

Conclusion. Based on the results of the research and discussion it was concluded that the cause of crossing water retribution in the Province of South Sumatra in 2017 has decreased due to uncooperative retribution payers factor paying retribution, both individuals and companies
\end{abstract}

Keywords: water crossing retribution; revenue sources.

\section{удк 336.2}

Зазілі Мустопа, докторант, Університет Шривіджая, Палембанг, Індонезія

Азварді, викладач факультету економіки, Університет Шривіджая, Палембанг, Індонезія

\section{Фактори зменшення надходжень за водні переправи як одного з регіональних джерел доходу Південної Суматри у 2017 році}

Анотація. Результати вивчення регіональних джерел доходів провінції Південна Суматра свідчать про наявність проблеми, що стосується надходжень за водні переправи. Зазначені надходження зменшилися протягом 2013-2014 рр., різке зменшення відбулося у 2015 році. Метою дослідження є визначення факторів, що призводять до зменшення надходжень за водні переправи у провінції Південна Суматра. Методика збору даних базувалася на інтерв'ю, спостереженні та документації. Для аналізу даних використано якісний аналіз.

Результати дослідження свідчать, що причиною зменшення надходжень за водні переправи у провінціі Південна Суматра в 2017 р. була відмова платників (як фізичних, так і юридичних осіб) від оплати рахунків. Відмова була і щодо оплати за прострочені платежі, навіть після отримання платниками відповідних рахунків. Найбільш суттєвим фактором була відмова від сплати відшкодування згідно з виписаним векселем. Причиною цього, як зазначили платники, стала невідповідність між послугами та сумою збору, яка повинна бути сплачена. Крім того, існували також компанії, які відмовлялися здійснювати оплату через велику суму відшкодування. Таким чином, основною причиною зменшення надходжень за водні переправи у провінції Південна Суматра у 2017 р. стала відмова як фізичних так і юридичних осіб від оплати рахунків.

Ключові слова: плата за водні переправи; джерела доходів.

Problem statement. Regional own source revenue is a number of assets owned by a region as a source of funds in the operation of the region. From this income, a region can build infrastructure, finance education, and improve public facilities as a form of business in improving people's welfare. Local revenue becomes an asset that needs to be 
maintained and managed properly by the government to improve the quality of life in the region. Therefore, local revenue is an autonomous right for the region. The regional government must actually issue beneficial policies for the survival of the region. In this case the local revenue management becomes a form of central government trust to local government ability in managing their regions, and a form of local governments independency in managing natural resources and its potential.

Abdullah and Alim (2004) state that the purpose of regional autonomy is to improve welfare and service to the society, to develop democratic life, justice, equity and to maintain harmonious relations between the center, the regions and other regions. To achieve this goal, the regional government can carry out an activity known as "regional loan". It has been conveyed by Siagian who argues that "organizational effectiveness is closely related to the use of existing sources of funds, power, facilities and infrastructure".The aim is that the Regional Revenue Budget (AnggaranPendapatanBelanja/APBD) funds can be used for the construction of physical facilities and improving the quality of services to the community by always being innovative, creative, and efficient by the regional government. Therefore, the government through the revenue service must be able to manage regional income as optimally as possible. If it is not managed optimally, then the level of regional income will decrease or be unstable.

The types of regional income as sources of regional wealth are very diverse, one of which is the crossing water retribution. Well-managed retribution funds can increase regional income, when it is not managed properly it can affect regional income. Management of retribution funds is a source of regional wealth that must be optimally explored.

Munawir (2008) explains that, "retribution is a contribution to the government that can be forced and the returned service can be directly appointed. This coercion is economic, because anyone who does not accept the service from the government is not charged for this contribution. The small contribution of Regional own source revenue as a barometer of the level of regional independence in carrying out the mandate of regional autonomy, in accordance with Law Number 32 of 2004, it requires the Regional Government to continually strive to increase regional own source revenue as the main source of regional income, fairly and accountably by considering the condition of the people who are the subject of Regional Revenue.

In South Sumatra the Province, the regional revenueas the source of income is the water crossing retribution. This retribution is taken from the people who use water crossing, then managed by the provincial government through the Regional Revenue Service. However, the funds from water crossing retribution in South Sumatra province for the last five years have been unstable, experiencing anincreaseand decrease income.

Documentation research results at the Regional Revenue Service of the Province of South Sumatra indicated a problem, especially in the water crossing retribution, namely a decrease in income from water crossing from 2013 to 2014 total of Rp. 374,169,677,639, and decreased dramatically again to Rp. 2,170,078,883in 2015 , so that crossing water retribution became Rp. 47,350,000.00. More details in the table below (table1).

Table 1. Water Crossing Retribution Income of South Sumatra Province in 2011 - 2015

\begin{tabular}{|c|c|c|}
\hline No & Year & Income \\
\hline 1 & 2011 & Rp. $1.511 .047 .337,07$ \\
\hline 2 & 2012 & Rp. $2.289 .785 .281,16$ \\
\hline 3 & 2013 & Rp. $2.591 .598 .560,64$ \\
\hline 4 & 2014 & Rp. $2.217 .428 .883,00$ \\
\hline 5 & 2015 & Rp. $47.350 .000,00$ \\
\hline
\end{tabular}

Source: South Sumatra Regional Revenue Service, 2017

From the data above, it can be seen that there was a very large decrease in water crossing retribution in 2015. The reason for the decreasing income, according to Syafuddin, head of sea transportation and Transportation rivers, lakes and Crossing(ASDP) (interviewed on May 29, 2017) was none deposit of retribution income from port service units in 2015. In the following year, 2016, retribution revenue from port service units was again targeted to be Rp.1,413,000,000, but reports on realization data were not yet received.The researcher assumed that there was a significant decline on water crossing retribution in 2015 . It assumed that there was a failurein the aspects of administration and management of financial statements. Therefore, the researcher intends to find out the Factors Decreasing Water Crossing Retribution as One of Regional Sources Revenue of South Sumatra Province in 2017.

Research Problems. Based on the background above, the formulation of the problem in this study which are the factors that cause a decrease in the revenue of water crossing retribution of South Sumatra Province?

Research Objectives. The purpose of this study was to find out the factors that cause the decrease in the revenue of water crossing retribution of South Sumatra Province? 


\section{Literature Review}

1. Previous Related Study

Some researches that discussewater crossing retribution has been previously examined by previous researchers. Wani (2016), Journal entitled: "Effectiveness Analysis and Contribution of Surface Water Taxes to Regional Revenues of North Sulawesi Province". The variable of this research was the growth of surface water tax in North Sulawesi Province. Data collection used observation, interviews, and documentation. The results of the study concluded that the growth of surface water tax had decreased from year to year, the highest growth of surface water tax in 2011 was $212.59 \%$ and the lowest growth in 2015 was $37.25 \%$. The effectiveness level of surface water tax revenues in North Sulawesi Province in 2011-2015 was effective. Surface water tax has not had a large contribution to the Regional revenue of North Sulawesi. The previous study has similarities with this research, which were both examining the acceptance of surface water tax or tax water crossing transportation retribution. The difference was that Wani used a quantitative descriptive method while this research used qualitative methods.

Indrakusuma (2009), a journal entitled: "Potential Revenue and Effectiveness of Street Lighting Tax in Semarang City". Data collection used observation, questionnaires, and documentation. The results of Arieyani's research concluded that there was a very large difference between the potential of street lighting tax revenues in the city of Semarang and the target set by the DPKAD in Semarang, which was Rp. 223,558,151,084. Customers from the industrial tariff group were the biggest contributors to the potential of street lighting tax revenues in the city of Semarang, which wasRp. 178.990.164,392.The results of the calculation of street lighting tax effectiveness in the city of Semarang from 2003 to 2009 as a whole was less than $100 \%$. It indicated that the effectiveness of street lighting tax in the city of Semarang was quite effective. The research carried out by Indrakusuma had the same thing, both examined road tax. The difference was that Indrakusuma examinedon street lighting taxes while this study examinedon water crossing tax.

Fajriana (2016), a journal entitled: "Implementation of Vehicles Tax Collection on the Water surface in Palembang City by the Regional Revenue Service of South Sumatra Province". The research variable was the implementation of vehicles tax collection on water surface. Data collection used observation, interviews, and documentation. The results of the study concluded that the implementation of tax collection in the process of data collection and registration, a vehicle owned by a person registered as a vehicle registered at the Department of Transportation.Then in the determination and collection process carried out by the Regional Technical Implementation Unit of Palembang (UPTD), where the vehicle was the subject to tariff of $1.5 \%$ according to the specifications based on grostonasi and horsepower of the vehicles. Efforts were made to overcome the constraints of socialization and supervision in the form of raids carried out by the UPTD of Palembang. The research conducted by Icha both examined the tax on vehicles on water surface, the difference was that Icha used qualitative data analysis method while this study used qualitative method.

2. Theoretical Frameworks

This research was conducted using theories that became the basis for conducting research. The theories are.

\section{a. Definition of Regional Retribution}

According to Law no. 28 of 2009, retributions are regional revenue as payments for services or special permits granted specifically and / or provided by the Regional Government for personal or agency interests. In contrast to the central tax such as Income Tax and Value Added Tax managed by the Directorate General of Taxes, revenue which can be called Regional Taxes are managed by the Regional Revenue Service (Dispenda) (https://id.wikipedia.org/wiki/Retribution, downloaded November 2018).

Ahma and Yani (2002: 55), state that the provincial, regency / city regions are given the opportunity to explore the potential of their financial resources by determining the types of revenue than other, as long as they met the criteria determined and were in accordance with the aspirations of the society.

Siahaan (2005: 6), regional retributions are regional the collection of payments for services or the provision of certain permits specifically provided and / or given by local governments for the benefit of individuals or firms.

Based on the opinions above, it can be concluded that, retribution is a particular payment or service specifically provided and / or given by the local government for the benefit of individuals or firms. Regional retributions are managed by the regional government.

b. Characteristics of Regional Retribution

According to the Director General of Central and Regional Fiscal Balance, Ministry of Finance-RI (2004: 60), Contributions of retribution on the Regional own source revenue, District / central government which is relatively constant needs to get serious attention for the regions. Because theoretically, especially for districts / cities retribution should have a greater role / contribution to Regional Revenue.

\section{c. Water Crossing Retribution}

Pigeu in Fajriana (2016: 4) explains that taxes can be used to correct the effects of negative externalities. In principle, pigovian tax is the tax imposed on each unit of output imposed on a balanced amount with the marginal cost of damage caused. Regional income is all regional rights recognized as increasing net worth in a certain budget period. Regional income derived from the receipt of central and regional balance funds, also comes from the region; regional income and other legitimate income (Waani, 2016: 670). 
Water Surface retribution is all income obtained from transportation crossing water surface. Water surface is all water found on the surface of the land, not including sea water, both at sea and on land (Siahan, in Waani, 2016: 670).

Based on the opinion above, it found that the crossing retribution water surface is a financing or collection of crossing services on the water as a source of regional revenue.

\section{Research Methods}

\section{Research Type}

This research was qualitative research which used statistics and non-statistics to analyse the problem.

2. Research Subjects and Objects

The subject of this research was the Department of Transportation of South Sumatra Province. The object of the research was the community of water crossing transportation users who were found during the study, 20 respondents were taken as the samples.

\section{Method of collecting data}

According to Sugiyono (2013: 24), research methods are scientific ways to obtain data with specific purposes and uses. Data collection in this study was conducted using interviews, observation, and documentation. More details as follows:

\section{1) Interview}

Interview is a data collection tool used to gather the opinion of the resource by asking questions to the informant. In this study, interviews were used to gather opinions of taxpayers and road users or water crossings transportation. The form of interview used was a closed interview totaling 10 questions. The respondents in this study were 10 people who crossed the water.

\section{2) Observation}

According to Sanjaya (2013: 274), observation is an instrument used to collect the data through observing. In collecting data, observation data used instruments as a guide for observers to record the results about the materials of observation. Observation is a data collection instrument. In this study, observations were used to observe crossing activities in the waters crossing activities of South Sumatra the Province. The instruments used in observation are observation guidelines.

\section{3) Documentation}

Documentation is a data collection instrument that is carried out by conducting documents research. In this study, the required documents are books, and reports on receipt of crossing retribution on water.

4. Data Analysis and Analysis Techniques

The data analysis used in this research was qualitative data analysis.

Findings and Discussion. The collection of crossing retribution on water transportation in South Sumatra Province is carried out by the Transportation Office of Palembang City. The process of collecting retribution is carried out with the principles, first, at the Transportation Office of Palembang, the principle of retribution is in accordance with those stated in regional regulations. Retribution officers only carry out the task of collecting funds from retribution payers provided that they do not deviate from the applicable provisions. Second, Measuring the level of service use.The use of crossing services on water at the Transportation Office of Palembang is carried out by looking at the monthly reports of each officer in each Regional Technical Implementation Unit (UPTD). Third, Structure and Tariff. The process of collecting crossing retribution on water transportation at the Transportation Office of Palembang was carried out structurally, where collection in the field was carried out from superiors to retribution collectors. The amount tariff given at about Rp. 2,000, up toRp. 5000per days for a person crossing services.

Fourth, the collection area. The retribution collection area at Transportation Office of Palembang was conducted at four UPTDs. Fifth, Determination of Payments. Determination of retribution payments is according to local regulations. In the collection process, officers from each field give a report to the treasurer of each type of retribution service per month, however the administration was not in good administration, so the detailed results per day are not reported. Fifth, administrative sanctions.

Administrative sanctions for late payments are not strictly enforced. Itis supported by the absence of detailed written reports. In an interview conducted on July 7, 2017, employees working at the Transportation Office of Palembang stated that the Transportation office did not receive daily reports, only received monthly reports at the end of each year. Based on the report, the treasurer of the Transportation Office made a report back for the annual results according to the reports of each designated officer.It becomes an obstacle in the collection process causing a report is not well detailed. In addition, officers in field did not make daily reports due to lack of socialization in the accounting system. Sixth, Billing. Billing on the Transportation Office is carried out regularly, every day continuously. Billing is carried out by appointed officers directly on compulsory retribution.

Various factors can be obstacles in the process of collecting crossing retribution in water transportation found. The factors that become obstacles are examined basedonaspects such as (1) crossing users in water transportation who do not pay for watercrossing retribution, (2) management of tax collection on water transportation, (3) less professional and untrusted, and (4) uncertainty about the realization of crossings water transportation budget.The four aspects, summarized briefly, are as follows: (a) retribution laws of, (b) retribution officers, and (c) taxpayers. Factors that become obstacles in implementing the collection of water crossing retribution at the Transportation Office of Palembang are as follows:

a. Constraints in the implementation of legislation 
Interview questions submitted to the officers of Transportation Office of Palembang are directed at the four indicators. The results of the interview indicated that in the aspect of the law, obstacles were not found. The implementation of the retribution law ran smoothly and was accepted by the users of retribution services.

b. Retribution officers

The obstacles faced in collecting retribution found in the aspects of retribution and taxpayer collection officers. The results of the interview showed that, "in the aspect of collector officers and retribution taxpayer there are obstacles, frequently retribution taxpayers making payments is not in accordance with the due time and provides many reasons to avoid retribution given or billed. It makes difficult focollection officers, so they feel tired or bored.

\section{c. Retribution Payers}

From the implementation of the retribution collection, many obstacles were encountered. The results of the interview showedsome obstacles faced are as follows (1) the late payment by retribution payer after bill is given; (2) there is a retribution payer who does not pay retribution in accordance with the bill; (3) the existence of companies objected to pay the bill issued.

The purpose of this study was to determine the implementation process of collecting crossing retribution in water transportation at the Regional revenue of Palembang city and to find out the factors constraining the implementation process of collecting crossing retribution in water transportation at the regional revenue the original revenue of Palembang city. From the data obtained through interviews, observation and documentation, It was found out that the process of collecting water crossing retribution at the Transportation
Office was carried out in accordance with applicable procedures, namely through structured procedures and stipulated by the Regional Regulation number 14 of 2015.The retribution collection was carried out by retribution collectors to individual taxpayers and companies. Taxpayers will be subject to administrative finalty if they were late in paying bills.

Constraints faced as the cause of decreasing income are as follows: (1) the late payment by the retribution payers to pay after the retribution bill was given; (2) there were some retribution payers who did not pay retribution in accordance with the bill issued; (3) the existence of companies objected to pay the amount of retribution bill issued. Retribution payers violated and avoided bills affecting the size of South Sumatra's regional revenue. Among the factors found were aspects of collector officers and taxpayers who violated the agreement, often retribution payers made payments were not in accordance with the promised time and provided many reasons to avoid retribution bills given.

Conclusion. Based on the results of the research and discussion it can be concluded that the cause of the receipt of funds from water transportation and crossing retribution in South Sumatra Province in 2017 has decreased due to retribution payer factor who were uncooperative in payments bill issued, both for individuals and companies. The noncooperative attitudes were shown through the behavior in late payment of obligations, even after the retribution bill was given. The more concerning factor was that there users did not pay retribution in accordance with the bill issued. In addition, there were also companies objected to pay the amount of the retribution bill issued.

\section{References:}

1. Abdullah dan Alim (2004). Otonomi Daerah Sebuah Teori dan Refleksi. Jakarta: Grasindo.

2. Fajriana, Icha (2013) Pelaksanaan Pemungutan Pajak Kendaraan Di Atas Air Kota

Palembang Oleh Dinas Pendapatan Provinsi Sumatera Selatan. Forum Bisnis Dan Kewirausahaan Jurnal IImiah STIE MDP, 2 (2). pp. 114-129.

3. Indrakusuma, Arieyani Widyarti (2009). Potensi Penerimaan dan Efektivitas Pajak Penerangan Jalan di Kota Semarang. Jurnal berjudul.

4. Munawir (2008). Pengelolaan Pendapatan Asli Daerah di Era Otonomi. Bandung: Alfabeta.

5. Sanjaya, Wina (2013). Penelitian Pendidikan. Jakarta: Kencana Prenada Media.

6. Suhardan (2011). Manajemen Pendidikan. Bandung: Alfabeta.

7. Sugiyono (2013). Metode Penelitian Manajemen. Bandung: Alfabeta.

8. Sunyoto, Danang (2015). Penelitian Sumber Daya Manusia Teori, Kuesioner, Alat Statistik, dan Contoh Riset. Yogyakarta: CAPS.

9. Undang-undang Retribusi Daerah Nomor 13 Tahun 2013.

10. Waani, Intan Gloria Kartika (2016). Analysis of effectiveness and contribution to surface water revenue tax revenue region north sulawesi province. Jurnal EMBA, 1, 4(2016), 667-675. 